Research

\title{
Stable low-level expression of p2 I WAFI/CIPI in A549 human bronchogenic carcinoma cell line-derived clones down-regulates E2FI mRNA and restores cell proliferation control
} Timothy G Graves, Michael W Harr, Erin L Crawford and James C Willey*

Address: Departments of Medicine and Pathology, Medical University of Ohio, 219 Health Education Building, 3055 Arlington Avenue, Toledo, $\mathrm{OH}, 43614-5806$, USA

Email: Timothy G Graves - tgraves@meduohio.edu; Michael W Harr - mharr@meduohio.edu; Erin L Crawford - ercrawford@meduohio.edu; James C Willey* - jwilley@meduohio.edu

* Corresponding author

Published: 10 January 2006

Molecular Cancer 2006, 5:1 doi:10.1186/1476-4598-5-1
Received: 12 October 2005

Accepted: 10 January 2006

This article is available from: http://www.molecular-cancer.com/content/5/I/I

(C) 2006 Graves et al; licensee BioMed Central Ltd.

This is an Open Access article distributed under the terms of the Creative Commons Attribution License (http://creativecommons.org/licenses/by/2.0), which permits unrestricted use, distribution, and reproduction in any medium, provided the original work is properly cited.

\begin{abstract}
Background: Deregulated cell cycle progression and loss of proliferation control are key properties of malignant cells. In previous studies, an interactive transcript abundance index (ITAI) comprising three cell cycle control genes, $[\mathrm{MYC} \times \mathrm{E} 2 \mathrm{FI}] / \mathrm{p} 2 \mathrm{I}$ accurately distinguished normal from malignant bronchial epithelial cells (BEC), using a cut-off threshold of 7,000. This cut-off is represented by a line with a slope of 7,000 on a bivariate plot of P2I versus [MYC $\times E 2 F I$ ], with malignant BEC above the line and normal BEC below the line. This study was an effort to better quantify, at the transcript abundance level, the difference between normal and malignant BEC. The hypothesis was tested that experimental elevation of $\mathrm{p} 2 \mathrm{I}$ in a malignant BEC line would decrease the value of the $[M Y C \times E 2 F I] / P 2 I I T A I$ to a level below this line, resulting in loss of immortality and limited cell population doubling capacity. In order to test the hypothesis, a p2I expression vector was transfected into the A549 human bronchogenic carcinoma cell line, which has low constitutive P2I TA expression relative to normal BEC.
\end{abstract}

Results: Following transfection of $\mathrm{p} 21$, four A549/p2I clones with stable two-fold up-regulated $\mathrm{p} 2 \mathrm{I}$ expression were isolated and expanded. For each clone, the increase in $\mathrm{p} 2 \mathrm{I}$ transcript abundance (TA) was associated with increased total p2I protein level, more than 5 -fold reduction in E2FI TA, and I0-fold reduction in the [MYC $\times \mathrm{E} 2 \mathrm{FI}] / \mathrm{p} 2 \mathrm{I}$ ITAI to a value below the cut-off threshold. These changes in regulation of cell cycle control genes were associated with restoration of cell proliferation control. Specifically, each transfectant was capable of only I5 population doublings compared with unlimited population doublings for parental A549. This change was associated with an approximate 2-fold increase in population doubling time to 38.4 hours (from $22.3 \mathrm{hrs}$ ), resumption of contact-inhibition, and reduced dividing cell fraction as measured by flow cytometric DNA analysis.

Conclusion: These results, likely due to increased P2I-mediated down-regulation of E2FI TA at the GI/S phase transition, are consistent with our hypothesis. Specifically, they provide experimental confirmation that a line with slope of 7,000 on the $\mathrm{P} 2 \mathrm{I}$ versus [MYC $\times \mathrm{E} 2 \mathrm{FI}$ ] bivariate plot quantifies the difference between normal and malignant BEC at the level of transcript abundance. 


\section{Background}

Bronchogenic carcinoma (BC) is the leading cause of cancer-related death in the United States and most industrialized nations [1]. It is reasonable to expect that improved mechanistic understanding of $\mathrm{BC}$ will lead to reduced death rate through more effective prevention and treatment regimens.

In an effort to identify biomarkers that diagnose BC with more accuracy than cytomorphologic criteria, this laboratory developed and has employed a highly quantitative, quality controlled RT-PCR method, Standardized RT (StaRT)-PCR [2-4]. With StaRT-PCR, data from all experiments may be directly compared in the same database. This leads to synergistically increasing value of data over time as data accumulate. Also, because the data are all numerical and standardized, they are easily combined into interactive transcript abundance indices (ITAI). ITAI typically are more closely associated with the phenotype of interest and are more likely to yield clinically useful biomarkers than values for individual genes, either alone or in multivariate analysis [5-7]. Initially, StaRT-PCR was used to measure the transcript abundance (TA) values of fifteen cell proliferation control genes (including MYC, E2F1, p21, RB1, PCNA, cyclin D2, cyclin D3, and p53) [6]. Although TA values for any single gene did not accurately distinguish normal from malignant human bronchial epithelial cells (BEC), an ITAI in the form of [MYC $\times$ E2F1]/ p21 (using a cut-off value of 7,000 ) was accurate $[2,6,8]$.

In previous studies of the association between the [MYC $x$ E2F1]/p21 ITAI and malignancy, it was observed that there is substantial variation in transcriptional regulation of p21 among BC tissues [9]. In some BC samples, p21 expression is low relative to normal $\mathrm{BEC}$, and in others it is markedly elevated. For example, in some BC there is decreased p53 function mediated by a mutation in the p53 regulatory pathway (e.g. p14ARF deletion in A549) [10], resulting in inappropriately low p21 expression and an ITAI above 7,000. In this context, even relatively low levels of MYC and E2F1 are sufficient to cause loss of proliferation control. However, even in $\mathrm{BC}$ tissues with high $\mathrm{p} 21$, the $[\mathrm{MYC} \times \mathrm{E} 2 \mathrm{~F} 1] / \mathrm{p} 21$ ITAI value is nearly always above 7,000. This suggests that E2F1 and/or MYC are increased to high enough levels and compensatory pathways, represented by p21 TA level, are inadequate to ensure cell proliferation control.

The p $21^{\mathrm{WAF} 1 / \mathrm{CIP} 1}$ gene is a key regulator of cell cycling [9]. Up-regulation of p21 WAF1/CIP1, which occurs mainly at the transcriptional level $[11,12]$, is mediated primarily by the tumor suppressor p53 after genotoxic stress [13]. In turn, p21 protein interacts with cyclin-cdk complexes [14-16], associates with pRb protein [17], PCNA [18-20], GADD45 $[21,22]$, cooperates with 14-3-3 [23], and/or modulates the activities of DNA polymerase $\delta$ [24]. These molecular changes are associated with growth arrest [13], senescence, terminal differentiation, apoptosis, and contact inhibition [11]. These and other changes mediated by either p53-dependent [13] and/or p53-independent means (i.e. Sp1/Sp3, Smads, Ap2, STAT, and BRCA1 (reviewed in [25])) contribute to G1 [26] and G2 checkpoint control [27] and regulation of the cell cycle. Experimental up-regulation through ectopic p21 expression [2226] or stimulation of endogenous p 21 transcription [2830] results in controlled cell proliferation.

The purpose of these studies was to better quantify, as measured by TA values, the relationship among key genes associated with cell proliferation control. Based on previous studies, a cut-off threshold of 7,000 for the [MYC $\times$ E2F1]/p21 ITAI accurately distinguishes normal from malignant lung samples. The hypothesis was tested that this empirically derived cut-off is mechanistically determined and is a mathematical representation of the difference between normal BEC and malignant BEC. First, the malignancy ITAI genes MYC, E2F1, and p21 were measured in an additional set of primary normal and malignant lung samples to more firmly establish the threshold separating them. Then, experimental studies were conducted on the human BC line, A549. This line was chosen because it has down-regulated p21 expression, in part due to p14ARF deletions [10], resulting in an ITAI above the cut-off threshold of 7,000. If the hypothesis was correct, stable exogenous expression of p21 in A549 would decrease the ITAI ratio to a level that is below this cut-off. Four A549 clones $(1,29,30$, and 32) that express increased constitutive levels of endogenous and exogenous p21 were established. The mathematical relationship among TA values of the genes comprising the ITAI was measured and the effects on cell cycling and proliferation control were examined.

\section{Results \\ Determination of the ITAI cut-off value that separates normal from malignant BEC}

Previously, we reported that a cut-off threshold of 7,000 for the [MYC $\times$ E2F1]/p21 ITAI accurately distinguishes normal from malignant BEC [8]. An additional 65 normal and 31 malignant samples were assessed for this study and the results, combined with data from previous studies, are presented in Figure 1 and in Additional File 1. In these studies, sensitivity and specificity are greater than $90 \%$ for distinguishing normal from malignant BEC using a value of 7,000 for the ITAI. Among primary samples, there are numerous factors not present in cell lines that may contribute to false negatives and/or false positives. False positives (high index value in morphologically nonmalignant samples) may be due to poor sample quality and RNA degradation or incorrect morphological diagno- 


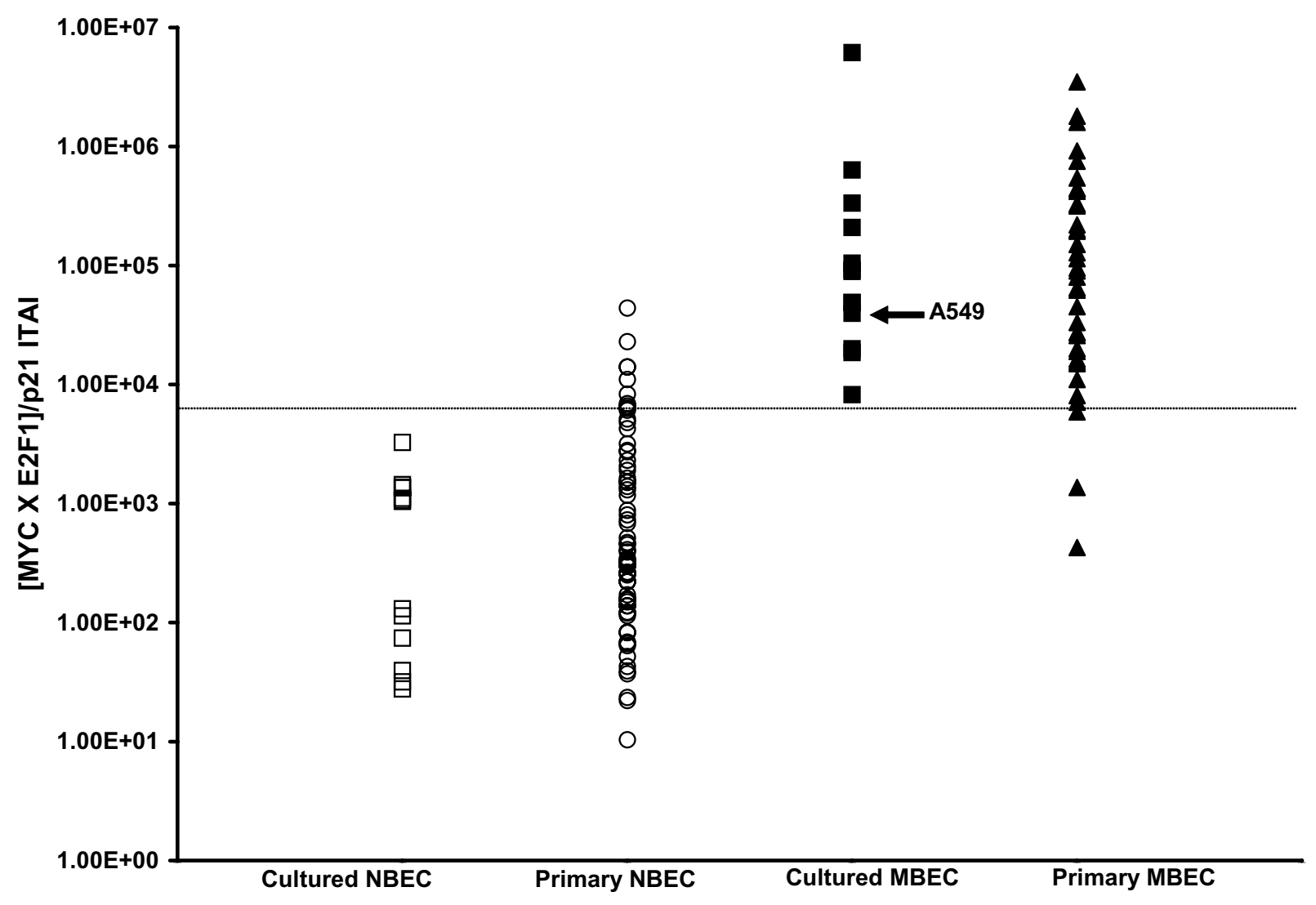

\section{Figure I}

Histogram analysis of the [MYC $\times$ E2FI]/p2 I ITAI. Each data set comprises either cultured or primary normal bronchial epithelial cell (NBEC) or cultured or primary malignant bronchial epithelial cell (MBEC) samples assessed for the ITAI. The ITAI cut-off is indicated by the horizontal line at 7,000 molecules. Parental A549 is indicated.

sis. False negatives (low index value in morphologically malignant samples) may be due to small fraction of tumor cells in the biopsy sample, or incorrect morphological diagnosis.

\section{Describing the ITAI threshold as a linear equation derived from cell cycle gene TA values}

Because the $[\mathrm{MYC} \times \mathrm{E} 2 \mathrm{~F} 1] / \mathrm{p} 21$ ITAI is a ratio between two values, the cut-off is best represented as a line on a bivariate plot. On a plot of all normal or malignant samples the ITAI threshold is represented as a line with a slope of 7,000 that passes through the origin (Figure 2). Thus, some malignant BEC have a very high p21 level and are above the cut-off only because they also have a very high [MYC $\times$ E2F1] value (e.g. H446), while others have a low p21 level and a relatively low [MYC $\times$ E2F1] level is sufficient to place them above the cut-off. In this way, the cut- off separates nearly all malignant from all normal samples. A549 is a good example of this phenomenon. The p21 TA level was higher than many normal BEC samples and the [MYC $\times$ E2F1] TA level was lower than some normal BEC samples. Yet, the p21 to [MYC $\times$ E2F1] ratio was above the ITAI cut-off.

\section{Expression of index genes and the ITAI in parental A549 and A549/p2 I clones}

Stable low-level expression of p21 RNA and protein were observed during screening of A549 clones 1, 29, 30, and 32 , and these clones were used in all subsequent studies. Doxycycline did not increase expression of p21 in these lines. Total p21 TA value (combined exogenous p21 plus endogenous p21 expression-see Methods) was significantly $(\mathrm{p}<0.05)$ increased two-fold in each of the A549/ p21 clones compared to the parental A549 (Figure 3). The 
increase in total p21 at the RNA level was associated with a corresponding increase in total $\mathrm{p} 21$ protein measured by Western blot analysis (Figure 4a). StaRT-PCR confirmed the expression of exogenous p21 TA in the A549/p21 clones (data not shown), and exogenous p21 protein expression was confirmed by Western blot analysis of the Hexa-His-tagged p21 (Figure 4b).

Expression of Hexa-His-tagged p21 was observed in each clone (lanes 2-5) but not in the parental A549 (lane 1). A higher molecular weight protein(s) was observed in the lysates from the clones suggesting a non-specific antigen/ antibody interaction. This increase in total p21 expression was associated with a greater than 5 -fold significant $(\mathrm{p}<$ $0.05)$ decrease in E2F1 TA in each clone (Figure 3). Further, the 2-fold increase in p21 TA and 5-fold decrease in E2F1 TA resulted in a greater than 10-fold significant ( $\mathrm{p}<$ 0.05 ) decrease in the ITAI in each of the A549/p21 clones relative to parental A549 (Figure 5a), to levels below the cut-off threshold of 7,000 (Figure 2 and 5b). With the exception of A459/p21 clone 1, there was no significant statistical difference in MYC TA among the remaining stable transfectants and parental A549 (Figure 3). Further, among the A549/p21 clones, variation in expression of $\mathrm{MYC}, \mathrm{E} 2 \mathrm{~F} 1$, and $\mathrm{p} 21$ and the resultant ITAI were insignificant.

\section{Growth kinetics of A549 and A549/p2 I clones}

Decreasing the ITAI to a level below 7,000 was associated with increased doubling time indicative of p21 effects on A549 proliferation kinetics. There was a nearly 2-fold increase in doubling time in each of the clones from 22.3 hrs for parental A549 to an average of 38.4 hrs in the four clones, in either antibiotic selection medium or antibiotic-free medium (Table 1). The rate of proliferation for the A549/p21 clones significantly $(\mathrm{p}<0.05)$ decreased $(0$ hrs to $72 \mathrm{hrs}$ ) and dramatically decreased after $72 \mathrm{hrs}$ with no significant change in number of cells between 72 and $96 \mathrm{hrs}$, and viability decreased at high saturation density (80\% confluency) (Figure 6). Despite variable seeding densities $\left(1 \times 10^{5}, 5 \times 10^{5}\right.$, and $1 \times 10^{6}$ cells $)$ of the A549/ p21 clonal populations, the cells ceased to proliferate and viability decreased at $80 \%$ confluency further suggesting p21-mediated contact inhibition at high saturation densities (data not shown). While the differences in proliferation rates were significant between parental A549 and the A549/p21 clones, there were no significant differences among any of the individual clones. Each of the A549/p21 clones was capable of approximately 15 total doubling times based on the estimated number of cells in the established initial foci $\left(\approx 1 \times 10^{2}\right.$ cells $)$ compared to the estimated number of cells in the seventh passage, which was the last passage that they were capable of (data not shown). These passage limitations are similar to the passage limitations of cultured normal BEC [28].

\section{Flow cytometric DNA analysis for A549 and A549/p2 I clones}

Decreasing the ITAI across the cut-off level between normal and malignant BEC was associated with p21-mediated cell-cycle arrest and/or delayed S-phase entry indicative of restored proliferation control. For the parental A549, 53.2\% and 36.9\% of cells were in G1 and Sphases respectively (Figure 7a). In contrast, in the A549/ p21 clones, the G1 fractions were increased to an average of $80.7 \%(73.7 \%, 85.4 \%, 76.3 \%$, and $87.3 \%$ in each respective clone) and the S-phase fractions were decreased to an average of $15.4 \%(21.4 \%, 10.6 \%, 19.1 \%$, and $10.3 \%$ in each respective clone (Figure $7 \mathrm{~b}-\mathrm{e}$ )

\section{Discussion}

Diagnostic tests, including those based on molecular diagnostic biomarkers, require establishment of a cut-off value to separate one clinically important phenotype from another. Cut-off values for multiple variables may then be combined through multivariate analysis to derive a diagnostic test with better accuracy than any of the individual cut-off values [5-7]. When attempting to approximate a complex phenotype through TA measurement, a significant limitation of multi-variate analysis is that it does not cause the individual variables to mathematically interact. It is not possible to deduce how the TA level of each gene scales with respect to a particular phenotype, nor how multiple genes interact at the TA level to give rise to a phenotype. It is likely that the scaling varies from one gene to another, and that interactions among the genes may involve both linear and non-linear functions. This is one reason that combination of TA values into ITAI leads to development of biomarkers with improved accuracy and ITAI biomarkers for clinical diagnostics have now been described [5-7]. It is important to recognize that the cutoff values for these ITAI represent lines on bivariate plots. One implication is that there is no prior reason that the best cut-off line will pass through the origin, as it does for the $[\mathrm{MYC} \times \mathrm{E} 2 \mathrm{~F} 1] / \mathrm{p} 21$.

A bivariate plot of $\mathrm{p} 21$ versus [MYC $\times$ E2F1] enables quantitative experimental investigation of the relationship between MYC, E2F1, and p21 individual transcript abundance values and the ITAI cut-off value that distinguishes normal from malignant BEC. For example, a malignant BEC line with a low [MYC $\times \mathrm{E} 2 \mathrm{~F} 1]$ value relative to most $\mathrm{BC}$ samples may be malignant if the p21 value also is relatively low. This was the case with parental A549. Although the A549 [MYC $\times$ E2F1] value is lower than in most malignant tissues (Figure 2), the ITAI value is above the cut-off threshold because the p21 level is low relative to the [MYC $\times \mathrm{E} 2 \mathrm{~F} 1]$ value. In contrast, a sample with a high p21 may be malignant if the [MYC $\times$ E2F1] value is sufficiently high, as was observed, for example, in the 


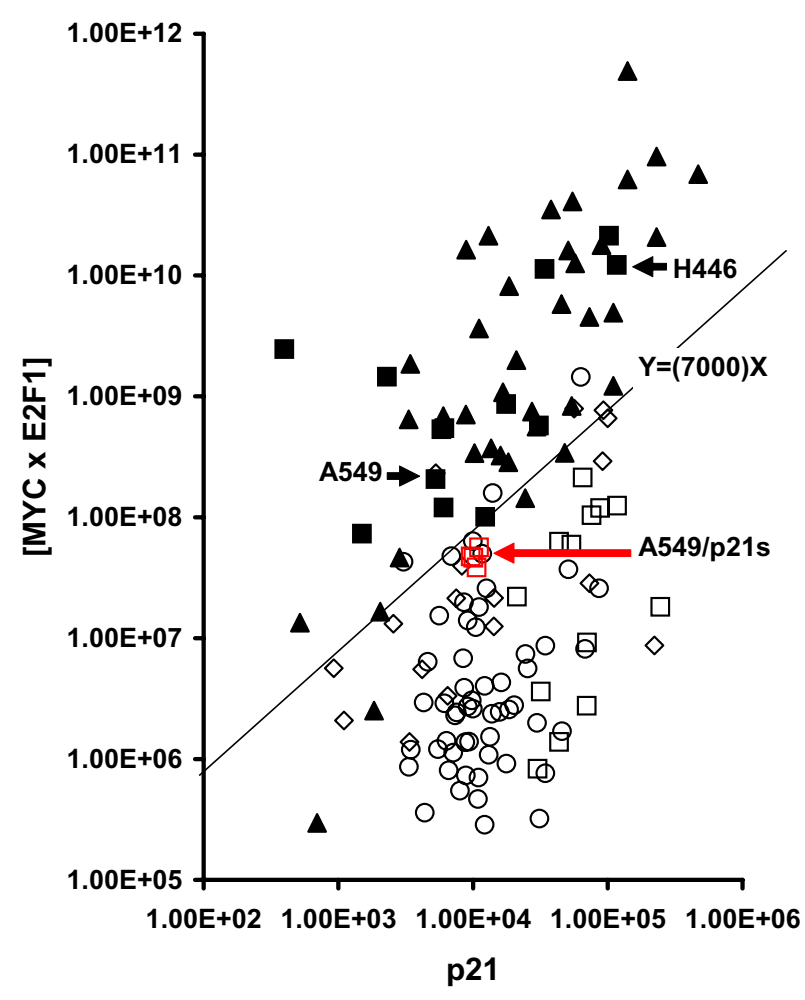

Figure 2

Bivariate analysis of $\mathrm{p2} I$ and [MYC $\times$ E2FI]. The $X-$ axis represents P2I TA while the $Y$-axis represents the expression product of [MYC $\times E 2 \mathrm{FI}$ ]. The cut-off value is indicated by a line with the slope of 7,000. Open symbols represent non-malignant (normal) BEC samples, while filledin symbols represent malignant BEC samples. All cultured BEC samples are indicated as squares. Primary normal BEC samples are indicated as circles, and primary normal parenchyma samples are indicated as diamonds. Primary malignant BEC samples are indicated as triangles. $\mathrm{H} 446, \mathrm{~A} 549$ and A549/p2I clones are indicated.

bronchogenic carcinoma cell line H446 (Figure 2, and [9]).

From these empirical observations, we selected the A549 cell line for subsequent experiments because its ITAI value was in close proximity to the cut-off threshold, and it was anticipated that even a relatively small increase in p21 TA value would be associated with restoration of cell proliferation control. Because it was anticipated that high constitutive expression of p21 would inhibit cell cycling to the extent that it would not be possible to isolate transfected clones, the goal was to obtain stable p 21 transfectants that were under control of a tetracycline inducible promoter. Because the tetracycline repressor was not functional in the transfectants, exogenous p21 expression was not repressed in the absence of tetracycline, but was constitu- tively active. Thus, two selection processes were operative. On the one hand, there was antibiotic selection for clones with stable integration of the transfected p21 expression vector. On the other hand, survival and clonal expansion also was dependent on a p21 expression level low enough to allow cell cycling. Therefore, while expression and growth kinetics varied significantly between A549 and the stable, constitutively expressing p21 A549-derived clones, the observed lack of clonal variation (insignificant differences in expression and growth kinetics among the A549/ p21 clones) supports these two selection processes. Each successfully isolated A549/p21 clone had total p21 expression that was elevated relative to parental A549, but was low enough to allow 15 doublings, which was sufficient for the studies reported here.

The absence of inducible clones could have been due to a number of factors, including promoter degradation, deleterious vector integration, and/or sub-optimal selection conditions affecting either the tetracycline repressor vector or the p21 expression vector.

In each A549/p21 clone we observed 1) a two-fold increase in p21, accompanied by 2) a 5-fold decrease in E2F1 TA and 3) that a 10-fold reduction in the ITAI was sufficient for each A549/p21 clone to cross the cut-off threshold of 7,000 . This was associated with marked reduction in cell cycle progression and cell proliferation in the A549/p21 clones.

p21 exerts its inhibitory function in either late G1 or late G2 of the cell cycle [26,27]. Consistent with this, our results demonstrate that in the A549/p21 clones, cell cycle arrest and delayed progression through the cell cycle was mediated at late G1 based on the average increase in the fraction of cells in G1-phase and the average decrease in Sphase of the clones relative to the parental cell line. Moreover, because E2F1 expression is important for S-phase progression (reviewed in [29]) and is up-regulated in A549 due, in part, to p14ARF deletions, which normally serves to suppress E2F1 both directly [30] and through inhibition of MDM2 leading to activation of p53 [31], it is reasonable to conclude that down-regulation of E2F1 mediated by up-regulated p21 expression contributed to growth inhibition at late G1. Because RB1 (retinoblastoma) is intact in A549 and is a substrate of cyclin-cdk function, inhibition of these regulatory complexes and/or $\mathrm{pRb}$ directly [17] by p21 may have contributed to decreased or inhibited $\mathrm{pRb}$ phosphorylation. This, in turn, would be associated with diminished E2F1 dissociation, decreased E2F1 auto-up-regulation [32,33] and attenuated progression through the cell cycle. However, another possibility has been reported, where p 21 has been shown to directly associate with E2F [34]. 


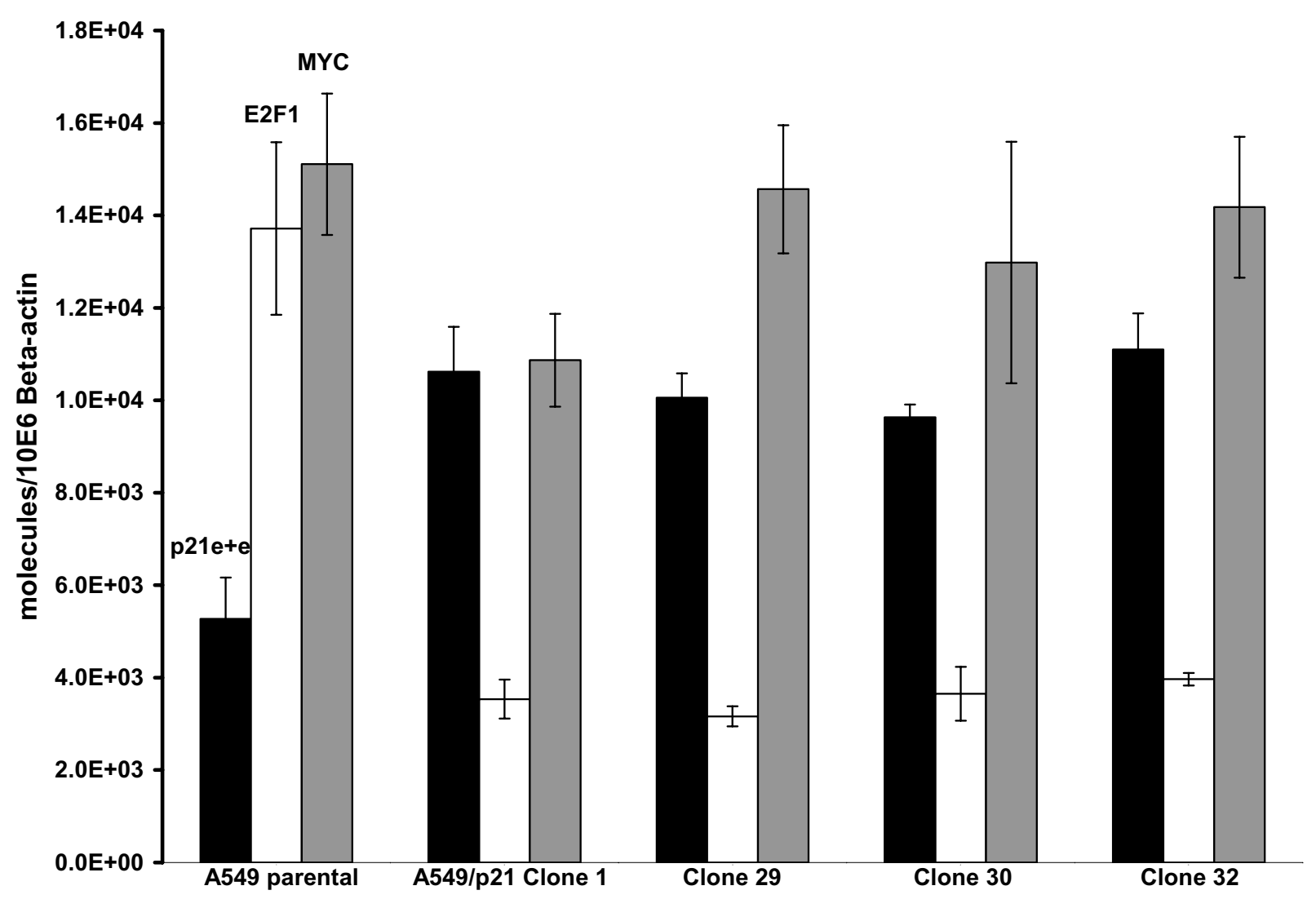

Figure 3

Combined endogenous plus exogenous p2I expression and E2FI and MYC expression for A549, A549/p2 I clone I, 29, 30, and 32. Total p2I TA levels (e + e: endogenous plus exogenous), E2FI TA levels, and MYC TA levels are indicated. Each column and error bar represents mean and standard deviation of at least triplicate measurements.

Table I: Doubling time for A549 and A549/p2 I clones.

\begin{tabular}{ccc}
\hline Sample & $\begin{array}{c}\text { Doubling time (hours) } \\
\text { w/ } \\
\text { antibiotic }\end{array}$ & $\begin{array}{c}\text { w/o } \\
\text { antibiotic }\end{array}$ \\
\hline A549 (parental) & $\mathrm{NA}^{3}$ & 22.3 \\
A549/p2I clone I & 39.3 & 38.5 \\
clone 29 & 39.5 & 38.2 \\
clone 30 & 39.3 & 39.3 \\
clone 32 & 38.2 & 37.7 \\
\hline
\end{tabular}

I) Doubling time was calculated by plotting the graph of cell count vs. time using the third degree polynomial. 2) Populations grown in 450 $\mu \mathrm{g} / \mathrm{mL}$ G4 18 (minimum lethal dose 100). 3) No growth of parental A549 in medium containing selectable antibiotic; all populations grown in RPMI and $10 \%$ FBS.
MYC TA level was not decreased considerably in the A549/p21 stable clones compared to the parental A549 in the context of a five-fold decrease in E2F1 TA level. This is in contrast to reports that in some contexts E2F1 is a transcription factor for MYC [35] and that reciprocal regulation occurs between MYC and p21 [36]. One possible explanation for this is that one or more transcription factors other than E2F1 contribute to MYC regulation. It is notable that a decrease in the ITAI to below the cut-off level, delay of cell cycle progression and re-establishment of proliferation control may be accomplished without significant alteration in MYC TA level, provided that sufficient alteration of p21 and E2F1 occur. Further, while MYC is a proven oncogene and increased expression of MYC causes oncogenic transformation in lung epithelial 


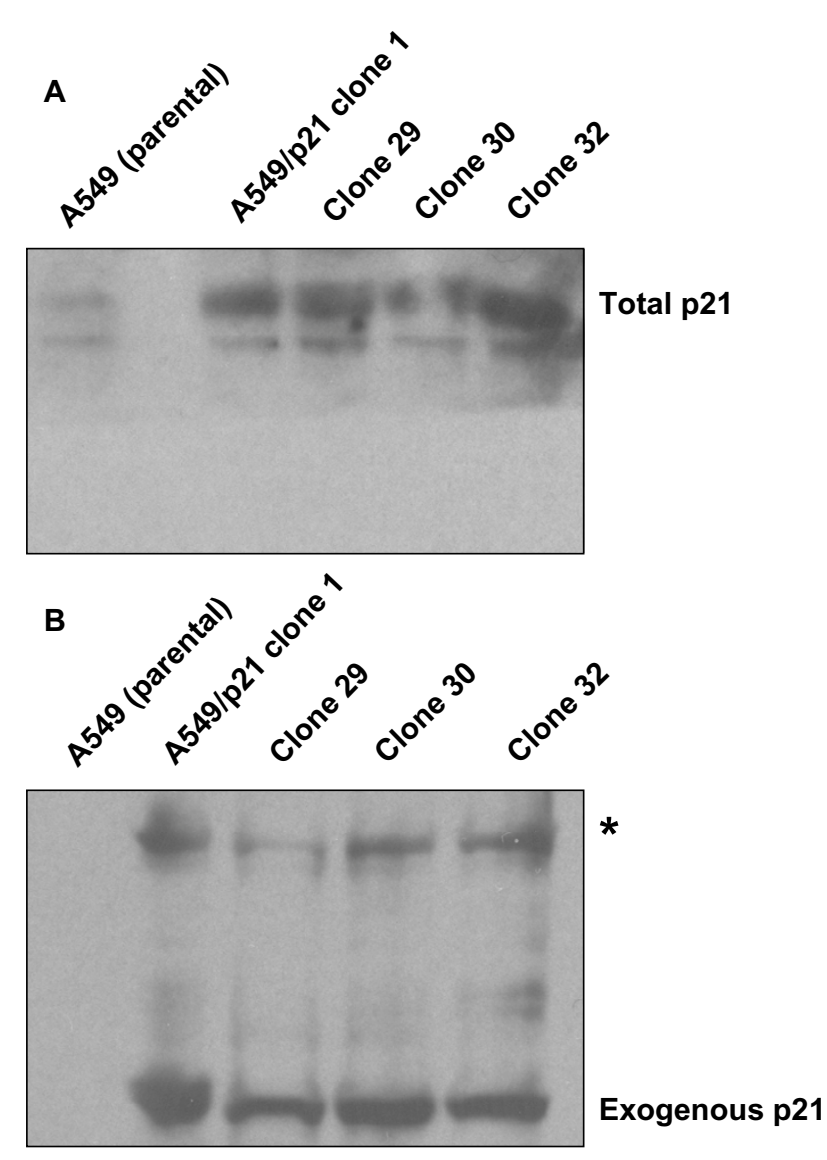

Figure 4

Western blot analysis of combined exogenous and endogenous $\mathrm{p} 2 \mathrm{I}$ protein and exogenous $\mathrm{p} 2 \mathrm{I}$ protein expression from A549, A549/p2 I clone I, 29, 30, and 32 cell lysates. A) Total p2 I protein was analyzed in parental A549 or A549/p2 I clones, which express stable low-level exogenous $\mathrm{p} 2 \mathrm{I}$. Twenty $\mu \mathrm{g}$ of lysate were blotted on a PVDF membrane and incubated with anti-Wafl (p2I) (Ab-I) primary monoclonal antibody. B) Exogenous $\mathrm{p} 21$ protein was confirmed in the A549/p2 I clones. Twenty $\mu \mathrm{g}$ of lysate were blotted on a PVDF membrane and incubated with anti-His Tag monoclonal antibody recognizing the Hexa-Histidine fusion tag of $\mathrm{p} 2 \mathrm{I}$ transactivated from the expression vector contained in the stable A549/p2 I clones. The asterisk indicates the non-specific antigen/antibody interaction.

cells (reviewed in [37]), these studies indicate that regaining MYC regulation is sufficient, but not necessary to reestablish cell cycle control in malignant cells. Others have made observations in other models consistent with those described here. For example, Boxer et al. observed that mammary adenocarcinomas that showed down-regulation of MYC retained their malignant properties and that transformation of residual neoplastic cells was independent of MYC expression [38].
Normal BEC exhibit contact inhibition in culture at particular cell densities and cellular senescence (irreversible growth arrest) [28]. Cessation of proliferation and loss of viability in the A549/p21 clones after 72 hrs of continuous high saturation density likely was mediated by up-regulation of $\mathrm{p} 21$. This response has been observed in melanoma cells over-expressing p21 [39]. This p21 effect may be mediated in part through the up-regulation of $\mathrm{H}$ cadherins [40] and/or T-cadherins independent of p53 [41]. Also, cell-to-cell contacts initiate prolonged nuclear localization of p21 that leads to growth arrest and apoptosis [39] and this effect may have been accentuated due to exogenous p21 up-regulation. Normal alveolar epithelial cells or A549 cells, exposed to sub-lethal doses of cigarette smoke, over-express p21 and undergo cellular senescence both in vitro and in vivo [42]. The cytokine, TGF- $\beta$, has been demonstrated to up-regulate p21 [43], and A549 cells treated with TGF- $\beta$ over a long period were forced to undergo senescence and senescent A549 cells were not tumorigenic in nude mice [44]. Increased p21 expression has been associated with G1 growth arrest and senescence in hepatoma cells treated with ninjurin 1 , a novel adhesion molecule that promotes regeneration in nervous tissue but senescence in liver tissue [45].

\section{Conclusion}

In conclusion, characterization of the role of p21 in regulating cell proliferation and better quantification of the balance among cell proliferation control genes, as measured by TA values, was achieved through a moderate upregulation of p21 in the A549 cell line. This allowed experimental quantitative confirmation that a cut-off level of 7,000 for the [MYC $\times$ E2F1]/p21 ITAI distinguishes between malignant and non-malignant phenotypes. This will guide development of more accurate diagnostic tests and more effective gene-targeted therapeutics.

\section{Methods}

\section{Cell lines and culture conditions}

The parental A549 cell line was cultured in RPMI 1640 with $10 \%$ fetal bovine serum (Clonetics, San Diego, CA). The A549/p21 clones 1, 29, 30, and 32 were continuously maintained in RPMI and 10\% Tet-system approved FBS (Clontech, Palo Alto, CA) with $450 \mu \mathrm{g} / \mathrm{mL}$ Geneticin (G418 sulfate) (Invitrogen, Inc., Carlsbad, CA) unless otherwise noted.

Culture conditions for normal and malignant BEC were described previously [3]. Normal and malignant BEC proliferate optimally under different conditions [46]. The medium that is optimal for malignant BEC, RPMI with $10 \%$ fetal bovine serum (Clonetics, San Diego, CA), induces terminal squamous differentiation in normal BEC [28]. Conversely, malignant BEC do not divide in serum-free medium that is optimal for proliferation of 


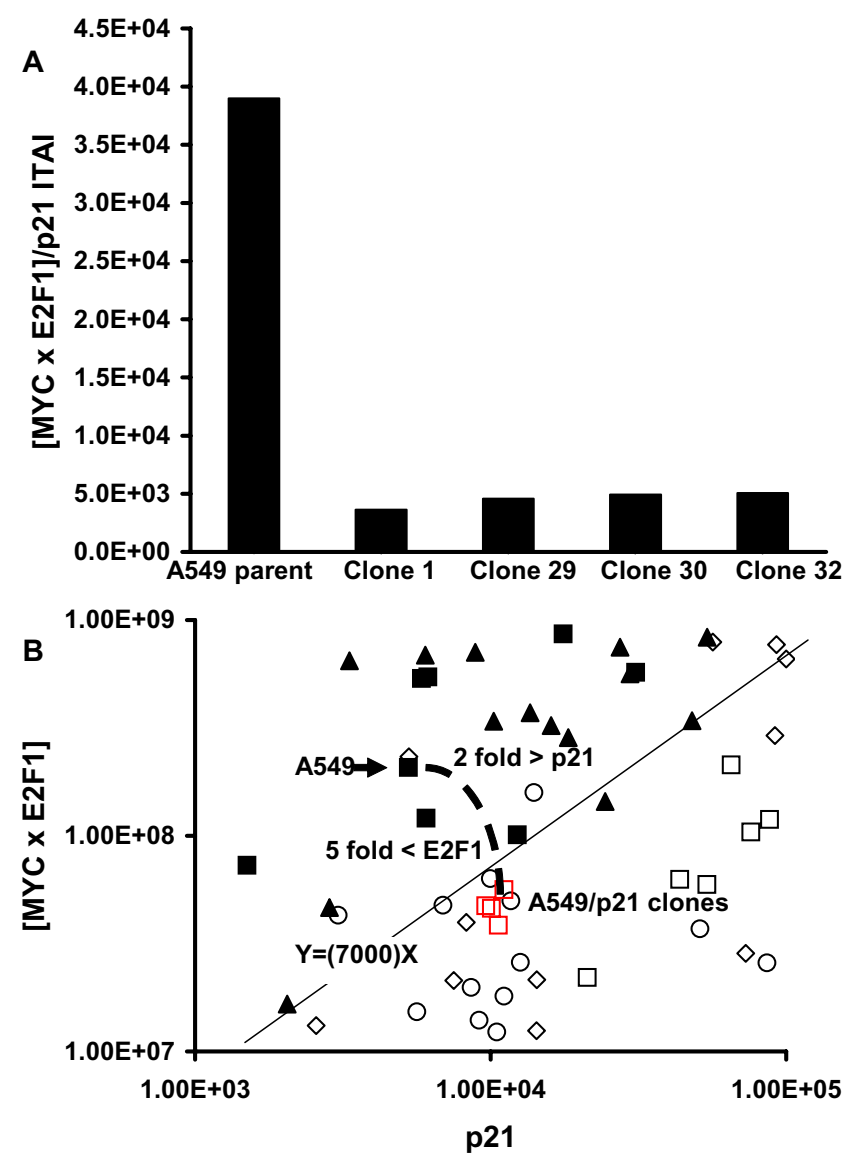

Figure 5

ITAI values and bivariate analysis for A549, A549/p2 I clone I, 29, 30, and 32. A) Mean TA value for each gene (from Figure 2) was used to calculate the ITAI. B) Bivariate analysis of $\mathrm{p} 2 \mathrm{I}$ and [MYC $\times$ E2FI] for parental A549, A549/ $\mathrm{p} 2 \mathrm{I}$ clones and samples in their vicinity that demonstrates the 2-fold increase in P2I, the 5-fold decrease in E2FI, and subsequent ITAI value that is below the cut-off threshold.

normal BEC. Thus, the 13 malignant BEC lines were cultured in RPMI with 10\% FBS and normal BEC from eight individuals (Clontech lot numbers: 10525, 17378, 6F0333, 6F0450, 17684, 17714, 6F0395, and 7F0075) were cultured in serum-free BEGM growth medium (Clonetics, San Diego, CA). In order to directly compare carcinoma cell lines to normal BEC under the same culture conditions, five of these normal BEC cell populations, 10525, 17378, 6F0333, 6F0450, and 17684 were incubated for 24 hours in RPMI with 10\% FBS directly prior to assessment (Additional File 1).

\section{Primary tissue samples}

Sixty-five primary normal BEC samples and thirty-one primary bronchogenic carcinoma samples (Additional File $1)$ were obtained under IRB approved protocols as described previously $[6,8]$.

\section{Construction and cloning of $\mathrm{p} 2 \mathrm{I}$ expression vector}

The GeneStorm hORF Expression Vector (pcDNA3.1/GS), containing the complete cDNA sequence of the cyclindependent kinase inhibitor 1A (p21, Cip1) (Accession L25610) was obtained from Invitrogen, Inc., (Carlsbad, $\mathrm{CA}$ ); The Gateway cloning system (Invitrogen, Inc., Carlsbad, CA) was used to create the p21 expression vector. Primers were designed to amplify the full-length p21 cDNA insert (Forward primer 5' end flanked by CACC, 5'CACCATGTCAGAACCGGCTGG ${ }^{3}$ and reverse primer 5'TCAATGGTGATGGTGATGAT ${ }^{3}$ ') were suitable for directional Topoisomerase (TOPO) cloning (Invitrogen, Inc., Carlsbad, CA) into pENTR/D-TOPO. To amplify the p21 complete cDNA from the pcDNA3.1/GS, the PCR conditions were $94^{\circ} \mathrm{C} / 15 \mathrm{sec}$., $58^{\circ} \mathrm{C} / 30 \mathrm{sec}$., and $72^{\circ} \mathrm{C} / 60 \mathrm{sec}$. for 35 cycles (slope $=9.9$ ) in an air thermocycler (Idaho Technology, Idaho Falls, Idaho). Each of five $10 \mu \mathrm{L}$ PCR reaction mixtures contained $2 \mathrm{mM}$ dNTPs, $10 \times, 30 \mathrm{mM}$ $\mathrm{MgCl}_{2}$, template (pcDNA3.1/GSp21), forward and reverse primers $(0.1 \mu \mathrm{g} / \mu \mathrm{L})$, Platinum Pfx DNA Polymerase (Invitrogen, Inc., Carlsbad, CA), and RNase-free water. After amplification, the five reactions were combined and electrophoresed in a $2 \%$ (NuSieve/SeaKem) agarose gel containing ethidium bromide. The PCR product was visualized under UV and extracted following the Qiagen gel extraction protocol (Qiagen, Santa Clarita, CA). The TOPO reaction was performed according to manufacturer's instructions. The pENTR/D-TOPO-p21 vector was isolated, quantified, and sequenced to confirm integrity and orientation. Next, the Gateway ${ }^{\mathrm{TM}}$ (Invitrogen, Inc., Carlsbad, CA) LR site-specific recombination system was used according to manufacturer's instructions to recombine the p21 ORF from the entry vector (pENTR/DTOPO-p21) with the destination vector (pT-RExDEST30), which contains two tetracycline operon (TetO2) sites within the human CMV promoter for tetracycline-regulated expression of the inserted gene.

\section{Stable transfection of cloned vectors}

A549 cells were trypsin-dissociated, and each well of a 24well dish was inoculated with $10^{5}$ cells (90-95\% confluent on the day of transfection) in $500 \mu \mathrm{L}$ of RPMI and 10\% Tet-system approved FBS (Clontech, Palo Alto, CA) without antibiotics. Twenty-four hours later, A549 cells were transfected with the pcDNA/TR vector (Invitrogen, Inc., Carlsbad, CA) that expresses the Tet-repressor. For each well of cells transfected, $1 \mu \mathrm{g}$ of vector DNA (pcDNA/ TR) was diluted into $50 \mu \mathrm{L}$ of Opti-MEM I Reduced Serum Medium (Gibco, Carlsbad, CA). Two microliters of Lipofectamine 2000 (LF2000) (Invitrogen, Inc., Carlsbad, CA) was diluted into $50 \mu \mathrm{L}$ of Opti-MEM I Medium (Gibco, Carlsbad, CA) and subsequent transfection was performed according to LF2000 manufacturer's instructions. At 24 hours post-transfection, the cells from each well were trypsin-dissociated and inoculated into correspond- 


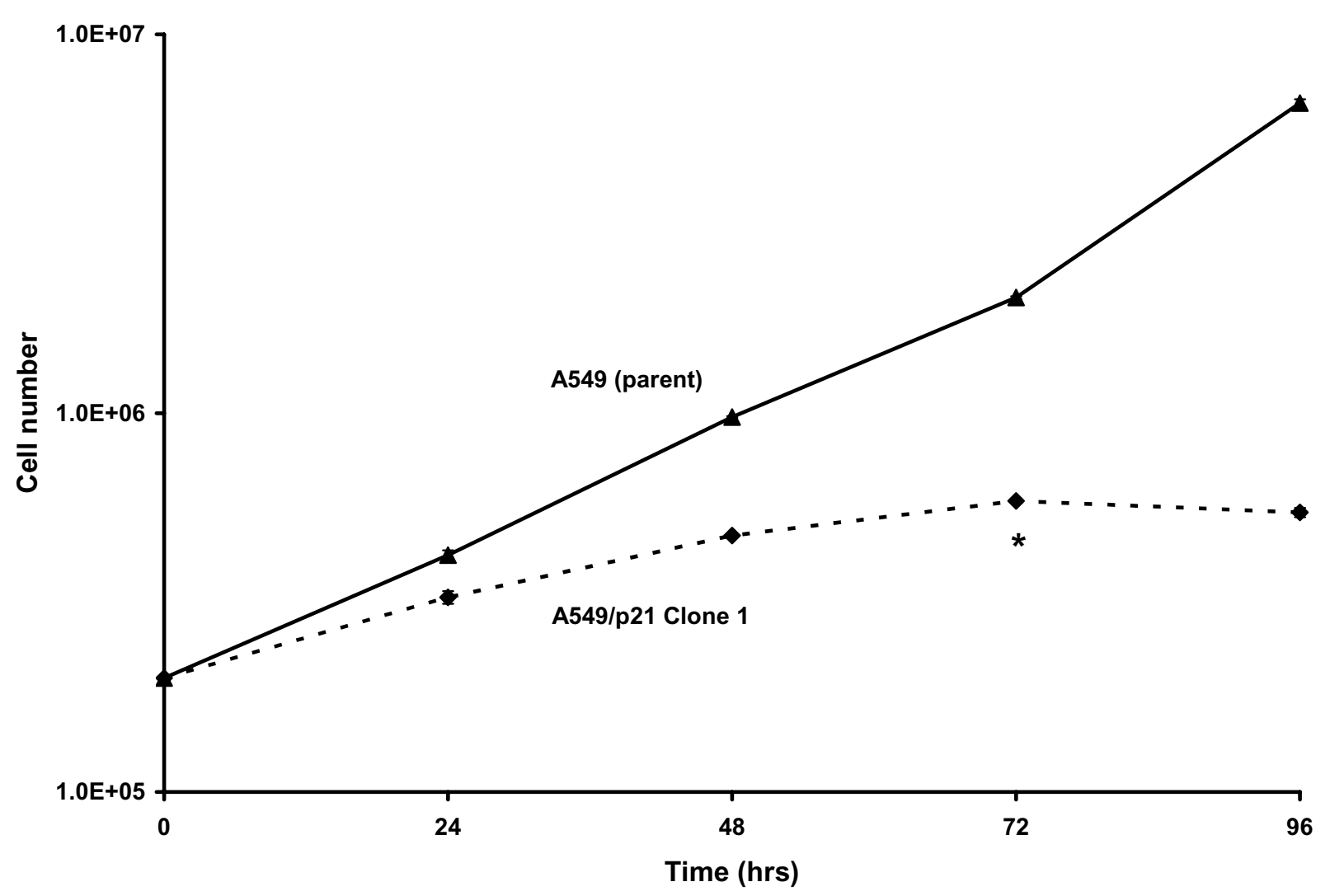

\section{Figure 6}

Proliferation kinetics for A549, and A549/p2I clone I. Thirty mm Petri dishes were inoculated with $2 \times 10^{5}$ cells from either parental A549, clone I, 29, 30, or 32, then incubated for $0,24,48,72$, or 96 hours. At each time point, cells were counted (total cell counts) and assessed for viability. Shown here are proliferation rates for parental A549 and A549/p2I clone I cell populations because while the growth rates are statistically significant between parental A549 and the A549/p2 I clones, the proliferation rates among the clones were statistically insignificant. The experiment was repeated in triplicate and data reported as mean +/- standard deviation. The error bars are too small to visualize on this scale. The asterisk at 72 hrs indicates the time point when clonal populations were approximately $80 \%$ confluent and exhibited decreased viability.

ing $10 \mathrm{~cm}$ plates containing fresh growth medium, RPMI and 10\% Tet-system approved FBS (Clontech, Palo Alto, CA) without antibiotics. The next day, selective medium was added containing blasticidin S-HCl (Invitrogen, Inc., Carlsbad, CA) at the A549 minimum 100\% lethal dose $\left(\mathrm{LD}_{100}\right)$ of $7 \mu \mathrm{g} / \mathrm{mL}$. Within one week, individual foci developed, and each of these were individually dissociated, transferred to a single well in a 24-well dish and cultured in selection medium. The pcDNA/TR-A549 clonal populations were expanded and then sequentially transfected with the pT-REx-DEST30-p21 response vector by means described above but using the A549 minimal $\mathrm{LD}_{100}$ for Geneticin (G418 sulfate) (Invitrogen, Inc., Carlsbad, CA) at $450 \mu \mathrm{g} / \mathrm{mL}$ as the selection antibiotic pressure. The pcDNA/TR/p21-A549 transfectants were maintained under dual blasticidin S-HCl and Geneticin selection. Lowest basal and the highest tetracycline-induced p21 TA level after addition of $1 \mu \mathrm{g} / \mathrm{mL}$ of doxycycline was assessed in passage 4 cells from each clone, with passage 1 being the passage of the initial double antibiotic resistant clones.

The initial screen for inducible exogenous p21 expression was done on cells from passage 4 of the A549/p21 clones. 


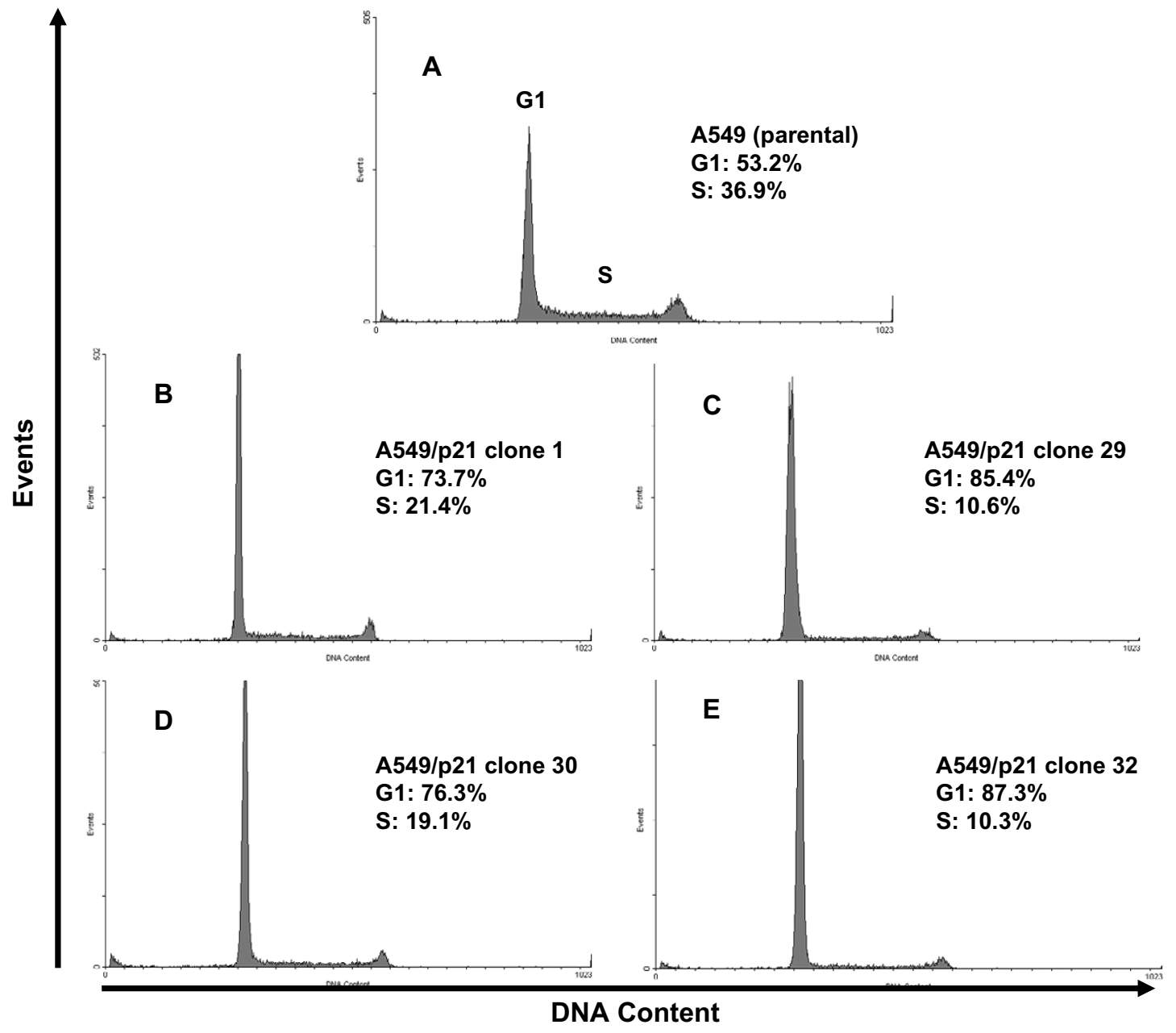

Figure 7

Flow cytometric DNA analysis on A549, A549/p2 I clone I, 29, 30, and 32. A) Determination of DNA content and events or cell number for parental A549 and A549/p2I clones constitutively expressing p2I (B-E) were performed as described in Methods and [50].

All mRNA, protein, flow cytometric, and growth kinetic assessments were performed at passage 5 and compared to parental A549 with an equivalent number of passages post-transfection.

\section{RNA extraction and reverse transcription}

For cultured or primary cells, pelleted cells were dissolved in TriReagent (Molecular Research Center Inc., Cincinnati, $\mathrm{OH}$ ) and total RNA was extracted according to manufacturer's instructions and previously reported methods [47]. Then, approximately $1 \mu \mathrm{g}$ of total RNA was reverse transcribed using oligo-dT primer and M-MLV reverse transcriptase (Invitrogen, Inc., Carlsbad, CA) as described previously [48].

\section{Quantitative standardized RT (StaRT)-PCR}

StaRT-PCR was used for all TA measurements [2-4]. For TA measurement of each gene, cDNA from a cell or tissue sample of interest was mixed with the internal standard (IS) for the gene within a standardized mixture of internal standards (SMIS). The presence of SMIS in each reaction enabled end-point quantification and controlled for all known sources of variation in PCR amplification, including inter-sample variation in the presence of gene-specific inhibitors. After PCR, $1 \mu \mathrm{L}$ of the PCR product was electrophoresed and quantified using an Agilent 2100 bioanalyzer according to manufacturer's recommended protocol (Agilent Technologies, Palo Alto, CA), and then each gene was quantified based on the ratio of the endogenous gene 
product (NT, native template) to its respective internal standard (IS) within the SMIS $[2-4,49]$. Because the initial concentration of IS added into the PCR reaction was known and it amplified with the same kinetics as the NT, the initial NT concentration could be determined through a ratio with the IS. Second, the calculated number of target gene NT molecules was divided by the calculated number of $\beta$-actin NT molecules to control for loading differences. Although $\beta$-actin was used as the reference gene for all measurements, it was possible to recalculate the data relative to any other single gene or combination of genes that was measured. Primers-(obtained from Gene Express, Inc; GEI, Toledo, $\mathrm{OH}$ ) for TA measurement in all cultured and primary samples of each gene comprising the ITAI (MYC, E2F1, and p21) and $\beta$-actin were described previously [2]. The $\mathrm{p} 21$ primers hybridize in the 3 ' untranslated region of the p21 cDNA. Therefore, in order to measure the p21 TA in A549 and the stable A549/p21 transfectants, another set of p21 primers (not commercially available) were designed to discern between exogenous expression of p21 (transcribed from the CMV-regulated p21 expression vector) and total p21 expression (endogenous plus exogenous). To specifically measure exogenous p21 TA, the reverse primer was anchored in the 3' Hexa-His-tag sequence that flanks the p21 ORF (reverse NT sequence, 5'GTGATGGTGATGATGACCG ${ }^{3}$ ' while the forward was ${ }^{5}$ ACCCTTGTGCCTCGCTCAG ${ }^{3}$ ). In order to measure total p21 exogenous plus endogenous TA level, forward and reverse primers ${ }^{5}$ GCCTGCCCAAGCTCTACCT ${ }^{3}$ and 5'GAGAAGATCAGCCGGCGTT'3', respectively, were designed that hybridize in the coding region of p21 and not the 3' Hexa-His-tag sequence. Previously reported data for TA measurement of MYC, E2F1, and p21 in cultured normal BEC, all malignant BEC except H146 (Additional File 1), and primary BEC were obtained using SMIS prepared in this laboratory [2]. More recent data were obtained using the same methods except SMIS used were those commercially available for StaRT-PCR from Gene Express, Inc. (Toledo, $\mathrm{OH}$ ). The previously published data then were converted to values based on the commercial SMIS. The conversion factor for each gene between the two SMIS was determined by evaluating a set of cDNA samples with each SMIS.

\section{Western blotting and antibodies}

Parental A549 and A549/p21 cells were lysed by three consecutive freeze-thaws in a $0.25 \mathrm{M}$ Tris lysis buffer (Invitrogen, Inc., Carlsbad, CA) and total protein concentration was determined colorimetrically by the bicinchoninic acid (BCA) assay (Pierce, Inc., Rockford, IL). Samples were solubilized in NuPAGE LDS Sample buffer (Invitrogen, Inc., Carlsbad, CA) and $20 \mu \mathrm{g}$ was loaded on a denaturing 7\% NuPAGE Tris-Acetate gel (Invitrogen, Inc., Carlsbad, CA). Protein bands were transferred to Invitrolon PVDF membranes (Invitrogen, Inc.,
Carlsbad, CA) as described by the manufacturer. Then, the membranes were blocked with 5\% non-fat dry milk in $1 \times$ TBST (blocking buffer) for $1 \mathrm{hr}$ at room temperature. For determination of exogenous p 21 protein expression, blots were incubated overnight with Anti-His Tag Mab (Novagen, Madison, WI) (1:2000) recognizing the Hexa-Histidine fusion tag of $\mathrm{p} 21$ transactivated from the expression vector contained in the stable A549/p21 clones. Blots were then washed with $1 \times$ TBST and incubated with the secondary antibody, HRP-conjugated anti-mouse IgG (Fisher, Pittsburgh, PA) (1:5000) for $1 \mathrm{hr}$ at $37^{\circ} \mathrm{C}$. Blots were washed three times with $1 \times$ TBST and once with $1 \times$ TBS. Detection was performed by the commercially available ECL detection system (Santa Cruz biotechnology, Santa Cruz, CA). For determination of total p21 protein expression (exogenous plus endogenous), blots were incubated with Anti-Waf1 (Ab-1) Mab (Oncogene Science, Cambridge, MA) (1:500). HRP-conjugated goat anti-mouse IgG (Santa Cruz biotechnology, Santa Cruz, CA) (1:2000) was used as the secondary antibody. Methodology was the same as described above. The Hexa-Histidine tag that flanks the ORF of p21 was necessary for determining expression of p21, both mRNA and protein, that was exogenously synthesized. To date, there is no evidence suggesting deleterious effects of Hexa-Histidine tags on the function of $\mathrm{p} 21$. Further, because the relative expression of His-tagged p21 was low in the A549/p21 clones, unexpected alterations in expression profiles and phenotype are less likely.

\section{Cell proliferation characteristics}

Sub-cultures of the clonal populations were maintained and periodically sub-cultured for determination of maximum number of passages at optimal confluency $(50 \%$ or $5 \times 10^{6}$ cells/T75 flask). To calculate the number of population doublings at each passage, the log 2 of the number of cells inoculated was subtracted from the $\log 2$ of the cell count for the cells harvested. This information was used to determine the number of population doublings for each clone.

Cell doubling time was determined by counting cells from trypsinized monolayers. Viability was assessed based on trypan-blue (Sigma-Aldrich, Saint Louis, MO) exclusion. $30 \mathrm{~mm}$ Petri dishes containing $2 \times 10^{5}$ cells from either parental A549, clone 1, 29, 30, or 32 were used for each time point $(0,24,48,72$, and $96 \mathrm{hrs})$. The stable clones were maintained with RPMI and 10\% FBS containing 450 $\mu \mathrm{g} / \mathrm{mL}$ G418. In order to rule out potential effects of the antibiotic on cell proliferation, the experiment was repeated in antibiotic-free medium. Both experiments were repeated in triplicate and the doubling time was calculated by plotting the graph of cell count versus time using the third degree polynomial. 
For further demonstration of growth characteristics of the A549/p21 clonal populations, variable numbers of cells $\left(1 \times 10^{5}, 5 \times 10^{5}\right.$, and $1 \times 10^{6}$ cells $)$ were inoculated per T75 flask for determination of percent confluency at which cells ceased dividing.

\section{Flow cytometry and determination of DNA content}

To determine DNA content and cell cycle phase, cells from the parental A549 and clones 1, 29, 30, and 32 were harvested at $50 \%$ confluency. Next, $1 \times 10^{4}$ cells were prepared for analysis by the propidium iodide, detergent, and trypsin nuclei method as described by Vindelov, et al., 1982 [50]. The cells were then evaluated for DNA content and cell number on an EPICS Elite Flow Cytometer (Beckman-Coulter Corp., Miami, FL, USA). Values were automatically calculated by Multicycle AV software (Phoenix Flow Systems, Inc., San Diego, CA, USA). Aggregates were excluded by pulse height versus pulse area.

\section{Graphic and statistical analysis}

Sensitivity and specificity were determined by $2 \times 2$ table analysis, and numerical variable differences were determined by paired-sample T-tests ( $\mathrm{p}$-value less than 0.05 was considered statistically significant) using SPSS 11.5.1 for Windows (SPSS, Chicago, IL). Determination of mean TA and cell number, standard deviation of TA and cell number, cell doubling time, and creation of graphs were accomplished using Excel 2000 (Microsoft Corp., Redmond, WA).

\section{Competing interests}

ELC and JCW each have significant equity interest in Gene Express, Inc., which produces and markets StaRT-PCR reagents used in these studies.

\section{Authors' contributions}

TGG conceived and designed experiments, and was responsible for TA measurement in cultured samples, construction and cloning of p21 expression vector, stable transfection of vector and construction of A549/p21 clones, preparation of the exogenous and endogenous and exogenous p21 SMIS, TA measurement in A549 and A549/p21 clones, Western blot analysis, cell proliferation characteristic analyses, prepared cells for flow cytometric DNA analysis, statistical analysis, and was the primary author of this manuscript. MWH was responsible for TA measurement in cultured samples and critical review of the manuscript. ELC was responsible for TA measurement in primary samples and critical review of the manuscript. JCW coordinated and obtained funding for the study and revised the manuscript.

\section{Additional material}

\section{Additional File 1}

TA, ITAI values and descriptions of all samples

Click here for file

[http://www.biomedcentral.com/content/supplementary/1476-

4598-5-1-S1.xls]

\section{Acknowledgements}

We would like to thank Drs. Dawn-Alita Hernandez, Youngsook Yoon, Jeffrey Hammersley, Ragheb Assaly, and Stacie Roshong-Denk for helping us acquire primary samples, and Tom Sawyer and Karen Domenico for the flow cytometric DNA analysis.

\section{References}

I. Jemal A, Murray T, Samuels A, Ghafoor A, Ward E, Thun MJ: Cancer Statistics, 2003. CA A Cancer Journal for Clinicians 2003, 53:5-26.

2. Willey JC, Crawford EL, Jackson CM, Weaver DA, Hoban JC, Khuder SA, DeMuth JP: Expression measurement of many genes simultaneously by quantitative RT-PCR using standardized mixtures of competitive templates. American journal of Respiratory Cell and Molecular Biology 1998, 19:6-17.

3. Willey JC, Crawford EL, Knight CA, Warner KA, Motten CR, Herness Peters E, Zahorchak RJ, Graves TG, Weaver DA, Bergman JR, Vondracek M, Grafstrom RC: Use of standardized mixtures of internal standards in quantitative RT-PCR to ensure quality control and develop a standardized gene expression database. A-Z of Quantitative PCR 2004:545-572.

4. Willey JC, Knight CR, Crawford EL, Olson DE, Hammersley J, Yoon $Y$, Sharief I: Use of standardized reverse transcriptionpolymerase chain reaction and the standardized expression measurement center in multi-institutional trials to develop meaningful lung cancer classification based on molecular genetic criteria. Chest 2004, 125: I55S-156S.

5. Crawford EL, Khuder SA, Durham SJ, Frampton M, Utell M, Thilly WG, Weaver DA, Ferencak WJ, Jennings CA, Hammersley JR, Olson DA, Willey JC: Normal bronchial epithelial cell expression of glutathione transferase PI, glutathione transferase M3, and glutathione peroxidase is low in subjects with bronchogenic carcinoma. Cancer Research 2000, 60(6):1609-1618.

6. DeMuth JP, Jackson CM, Weaver DA, Crawford EL, Durzinsky DS, Durham SJ, Zaher A, Phillips ER, Khuder SA, Willey JC: The gene expression index c-myc $\times$ E2FI/p2I is highly predictive of malignant phenotype in human bronchial epithelial cells. American Journal of Respiratory Cell and Molecular Biology 1998, 19:18-24.

7. Weaver DA, Crawford EL, Warner KA, Elkhairi F, Khuder SA, Willey JC: ABCC5, ERCC2, XPA and XRCCI transcript abundance levels correlate with cisplatin chemoresistance in non-small cell lung cancer cell lines. Molecular Cancer 2005, 4(I):

8. Warner KA, Crawford EL, Zaher A, Coombs RJ, Elsamaloty H, Roshong-Denk SL, Sharief I, Amurao Y, Yoon Y, Al-Astal AY, Assaly RA, Hernandez DA, Graves TG, Knight CR, Harr MW, Sheridan TB, DeMuth JP, Zahorchak RJ, Hammersley JR, Olson DE, Durham SJ, Willey JC: The c-myc $\times$ E2FI/p2I interactive gene expression index augments cytomorphologic diagnosis of lung cancer in fine-needle aspirate specimens. Journal of Molecular Diagnosis 2003, 5: 176-183.

9. Harr MW, Graves TG, Crawford EL, Warner KA, Reed CAM, Willey JC: Variation in transcriptional regulation of cyclin dependent kinase inhibitor p2 I wafl/cipl among human bronchogenic carcinomas. Molecular Cancer 2005, 4(23):

10. Lu W, Lin J, Chen J: Expression of pI 4ARF overcomes tumor resistance to p53. Cancer Research 2002, 62(5): $1305-1310$.

II. Noda A, Ning Y, Venable SF, Pereira-Smith OM, Smith JR: Cloning of senescent cell-derived inhibitors of DNA synthesis using an expression screen. Experimental Cell Research 1994, 2 I I:90-98. 
12. Sheaff RJ, Singer JD, Swanger J, Smitherman M, Roberts JM, Clurman BE: Proteasomal turnover of p2 ICipl does not require p2 I Cip I ubiquitination. Molecular Cell 2000, 5:403-4I 0 .

13. El-Diery WS, Tokino T, Velculescu VE, Levy DB, Parsons R, Trent JM, Lin D, Mercer E, Kinzler KW, Vogelstein B: WAFI, a potential mediator of p53 tumor suppression. Cell 1993, 75:817-825.

14. Gu Y, Turek CW, Morgan DO: Inhibition of CDK2 activity in vivo by an associated $20 \mathrm{~K}$ regulatory subunit. Nature 1993, 366:707-710.

15. Harper JW, Adami GR, Wei N, Keyomarsi K, Elledge SJ: The p2 I Cdk-interacting protein Cipl is a potent inhibitor of $\mathbf{G I}$ cyclin-dependent kinases. Cell 1993, 75:805-816.

16. Xiong Y, Hannon G], Zhang H, Casso D, Kobayashi R, Beach D: p2 I is a universal inhibitor of cyclin kinases. Nature 1993 366:701-704.

17. Nakanishi M, Kaneko Y, Matsushime H, lkeda K: Direct interaction of p2 I cyclin-dependent kinase inhibitor with the retinoblastoma tumor suppressor protein. Biochemical and Biophysical Research Communications 1999, 263:35-40.

18. Ando $\mathrm{T}$, Kawabe $\mathrm{T}$, Ohara $\mathrm{H}$, Ducommun $\mathrm{B}$, Itoh $\mathrm{M}$, Okamoto $\mathrm{T}$ : Involvement of the interaction between $\mathrm{p} 2 \mathrm{I}$ and proliferating cell nuclear antigen for the maintenance of $G 2 / M$ arrest after DNA damage. The Journal of Biological Chemistry 200I, 276(46):4297|-42977.

19. Chen J, Jackson PK, Kirschner MW, Dutta A: Separate domains of p2 I involved in the inhibition of cdk kinase and PCNA. Nature 1995, 374:386-388.

20. Waga S, Hannon G], Beach D, Stillman B: The p2I inhibitor of cyclin-dependent kinases controls DNA replication by interaction with PCNA. Nature 1994, 369:574-578.

21. Kearsey JM, Coates PJ, Prescott AR, Warbrick E, Hall PA: Gadd45 is a nuclear cell cycle regulated protein which interacts with p2 ICip I. Oncogene 1995, I I(9): I675-I683.

22. Vairapandi M, Balliet AG, Fornace AJ Jr, Hoffman B, Liebermann DA: The differentiation primary response gene MyD I 8, related to GADD45, encodes for a nuclear protein which interacts with PCNA and p2IWAFI/CIPI. Oncogene 1996, I 2(I2):2579-2594.

23. Chan TA, Hwang PM, Hermeking $H$, Kinzler KW, Vogelstein $B$ Cooperative effects of genes controlling the G2/M checkpoint. Genes and Development 2000, I4(I3): I584-I588.

24. Li R, Waga S, Hannon G], Beach D, Stillman B: Differential effects by the p2 I CDK inhibitor on PCNA-dependent DNA replication and repair. Nature 1994, 371:534-537.

25. Gartel AL, Tyner AL: Transcriptional regulation of the $\mathbf{p} 2$ (WAFI/CIPI) gene. Experimental Cell Research 1999, 246(2):280-289.

26. Dulic V, Kaufmann WK, Wilson SJ, Tlsty TD, Lees E, Harper JW, Elledge SJ, Reed SI: p53-dependent inhibition of cyclin-dependent kinase activities in human fibroblasts during radiationinduced GI arrest. Cell 1994, 76:1013-1023.

27. Bunz F, Dutriaux A, Lengauer C, Waldman T, Zhou S, Brown JP, Sedivy JM, Kinzler KW, Vogelstein B: Requirement for p53 and p2I to sustain G2 arrest after DNA damage. Science 1998, 282: |497-|50|.

28. Lechner JF, Haugen A, McClendon IA, Shamsuddin AM: Induction of squamous differentiation of normal human bronchial epithelial cells by small amounts of serum. Differentiation 1984, 25:229-237.

29. Dimova DK, Dyson NJ: The E2F transcriptional network: old acquaintances with new faces. Oncogene 2005, 24:28I 0-2826.

30. Mason SL, Loughran O, La Thangue NB: p I 4(ARF) regulates E2F activity. Oncogene 2002, 21 (27):4220-4230.

31. Weber JDTL, Roussel MF, Sherr CJ, Bar-Sagi D: Nucleolar Arf sequesters Mdm2 and activates p53. Nature Cell Biology 1999, I(I):20-26.

32. Araki K, Nakajima $Y$, Eto $K$, Ikeda MA: Distinct recruitment of E2F family members to specific E2F-binding sites mediates activation and repression of the E2FI promoter. Oncogene 2003, 22:7632-764I.

33. Ishida S, Huang E, Zuzan H, Spang R, Leone G, West M, Nevins JR: Role for E2F in control of both DNA replication and mitotic functions as revealed from DNA microarray analysis. Molec ular Cell Biology 2001, 2 I ( ( 4):4684-4699.

34. Delavaine L, La Thangue NB: Control of E2F activity by p2 I Waf।/ Cipl. Oncogene 1999, 18:5381-5392.
35. Rhee $\mathrm{K}, \mathrm{Ma} \mathrm{T}$, Thompson EA: The macromolecular state of the transcription factor E2F and glucocorticoid regulation of cmyc transcription. Journal of Biological Chemistry 1994, 269: I7035-I7042.

36. Kitaura H, Shinshi M, Uchikowski Y, Ono T, Tsurimoto T, Yoshikawa $\mathrm{H}$, Iguchi-Ariga SMM, Ariga $\mathrm{H}$ : Reciprocal regulation via proteinprotein interaction between c-Myc and $\mathrm{p2I}$ (cipl/wafl/sdil) in DNA replication and transcription. Journal of Biological Chemistry 2000, 275(2I): 10477-10483.

37. Zajac-Kaye M: Myc oncogene: a key component in cell cycle regulation and its implication for lung cancer. Lung Cancer 200I, 34:S43-S46.

38. Boxer RB, Jang JW, Sintasath L, Chodosh LA: Lack of sustained regression of C-MYC-induced mammary adenocarcinomas following brief or prolonged MYC inactivation. Cancer Cell 2004, 6(6):577-586.

39. Ritt MG, Mayor J, Wojcieszyn J, Smith R, Barton CL, Modiano JF: Sustained nuclear localization of P2I/WAF-I upon growth arrest induced by contact inhibition. Cancer Letters 2000, I58(I):73-84.

40. Zhong Y, Lopez-Barcons L, Haigentz M Jr, Ling YH, Perez-Soler R: Exogenous expression of $\mathrm{H}$-cadherin in $\mathrm{CHO}$ cells regulates contact inhibition of cell growth by inducing $\mathrm{p} 2 \mathrm{I}$ expression. International Journal of Oncology 2004, 24(6): 1573-1579.

4I. Huang ZY, Wu Y, Hedrick N, Gutmann DH: T-cadherin-mediated cell growth regulation involves $\mathbf{G} 2$ phase arrest and requires p2 I (CIP I/WAFI) expression. Molecular and Cellular Biology 2003, 23(2):566-578.

42. Tsuji T, Aoshiba K, Nagai A: Cigarette smoke induces senescence in alveolar epithelial cells. American Journal of Respiratory Cell and Molecular Biology 2004, 3 I (6):643-649.

43. Reynisdottir I, Polyak K, lavarone A, Massague J: Kip/Cip and INK4 cdk inhibitors cooperate to induce cell cycle arrest in response to TGF-beta. Genes and Development 1995, 9:1831-1845

44. Katakura Y, Nakata E, Tabira Y, Miura T, Teruya K, Tsuchiya T, Shirahata S: Decreased tumorigenicity in vivo when transforming growth factor beta treatment causes cancer cell senescence. Bioscience, Biotechnology, Biochemistry 2003, 67(4):815-821.

45. Toyama T, Sasaki Y, Horimoto M, lyoda K, Yakushijin T, Ohkawa K, Takehara T, Kasahara A, Araki T, Hori M, Hayashi N: Ninjurin I increases p2 I expression and induces cellular senescence in human hepatoma cells. Journal of Hepatology 2004, 4I(4):637-643.

46. Willey JC, Moser CE Jr, Lechner JF, Harris CC: Differential effects of 12-O-tetradecanoylphorbol-13-acetate on cultured normal and neoplastic human bronchial epithelial cells. Cancer Research 1984, 44:5I24-5I 26.

47. Chomczynski P, Sacchi N: Single-step method of RNA isolation by acid guanidinium thiocyanate-phenol-chloroform extraction. Anal Biochem 1993, 62:156-159.

48. Willey JC, Coy EL, Frampton MW, Torres A, Apostolakos MJ, Hoehn G, Schuermann WH, Thilly WG, Olson DE, Hammersley JR, Crespi CL, Utell MJ: Quantitative RT-PCR measurement of p450 $|A|$, IBI, and 2B7, microsomal epoxide hydrolase, and NADPH oxidoreductase expression in lung cells of smokers and non-smokers. American Journal of Respiratory Cell and Molecular Biology 1997, 17: I I4-124.

49. Willey JC, Crawford EL, Knight CR, Warner KA, Motten CA, Herness EA, Zahorchak RJ, Graves TG: Standardized RT-PCR and the standardized expression measurement center. Methods in Molecular Biology: Gene Expression Profiling: Methods and Protocols 2004, 258:13-4|.

50. Vindelov: A detergent-trypsin method for the preparation of nuclei for flow cytometric DNA analysis. Cytometry 1982, 3(5):323-327. 